\title{
Meaning and Philosophy in the Hungarian Economic Terminology
}

\author{
Gizella Frang \\ Faculty of Pedagogy, University of West Hungary, Hungary
}

Copyright $\bigcirc 2016$ by authors, all rights reserved. Authors agree that this article remains permanently open access under the terms of the Creative Commons Attribution License 4.0 International License

\begin{abstract}
Hungarian economic experts can only make a difference between global expectations and national interests. When creating their economic philosophy, they only take into consideration our native culture and the base of people's ways of thinking. The "interpretational scissors" between economic terminology and everyday language can only be reduced by bringing the economy and the common thinking in balance by using the same code system. This re-Hungarianized language used with consciousness as a common property can help us to solve the life-problems of our nation. The economic terms analyzed by the research of roots of language prove the ethical economic approach of our ancestors: economy served people living in a community, and until Hungarian reform times. It was not only as much important as everyday life required it, but based on trust and honour.
\end{abstract}

Keywords Culture, Civilization, Communication, Technical Terms, Interpretational Scissors

\section{Introduction, Intentions}

"To be Hungarian is not only a state, Let's understand it: it is a profession." (László Barabási)

During my last 25 years working as a journalist and a teacher - and as a civilian too - I saw that different terminologies are hard to understand for an average man. The media has enlarged this "interpretational scissors" between the economic terms and the everyday language. In the last 20 years, even the most frequently used phrases of economic terminology are difficult to understand for a non-specialist. Using the scheme of communication: there is a disharmony between the communicant and the listener in spite of the working communication channel.

I think it's not healthy but damaging for a society which aims to get around, that its language of economy is ambiguous depending on the speaker. It must be balanced! It is indispensable to come back to the ancient meaning of our language and revive the knowledge and thinking of it in the very last hour. We can get it by the research of roots of language which illuminates the real content of our idioms, the philosophy of our ancient life in harmony with nature. This re-Hungarianized language used with consciousness as a common property can help us to solve the life-problems of our nation.

I would like to know what kind of economic activity our words refer to and what kind of thinking they reflect.

We have to find and sort out the real Hungarian idioms from the fashionable phrases of language. Not because we should use archaic words today, but we must show that we can get rid of our new word adoptions and speak a Hungarian language without unnecessary international phrases and words (for example: ekvivalens=egyenértékü, egyenlő /equivalent; korrigál=kiigazít, helyrerak/correct; komplementer=kiegészítö/complementary; kaució=letét /caution; szektor=gazdasági ág /sector; transportál = fuvaroz, szállít /transport ect.). And last but not least we should make sure of our economic traditions in order to get self-confidence out of the history of economy reflected in the language.

However, we first have to clear several questions about language and community. 


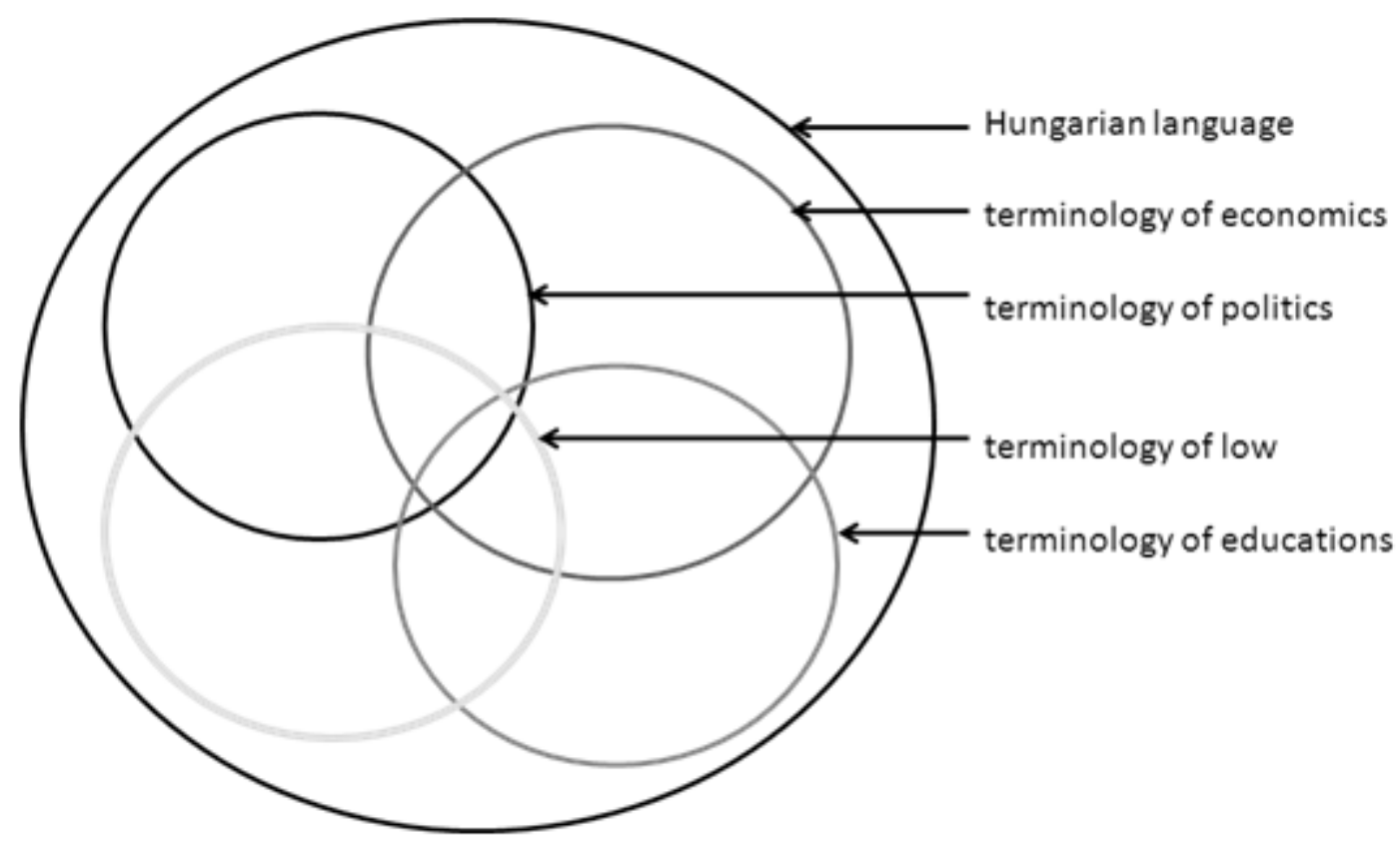

Figure 1. Terminologies

\section{Nation, Society and Language}

In spite of the fact that globalism people and their special culture have their own role in the economy, people are social creatures: part of coherent social groups whose base is the national culture, the collective wisdom built up in thousand years and the individual erudition, which are viable and renewable.

The largest cultural group for us is the nation. It is based on nationalities on one side and on sociological groups having similar cultural roots on the other side.

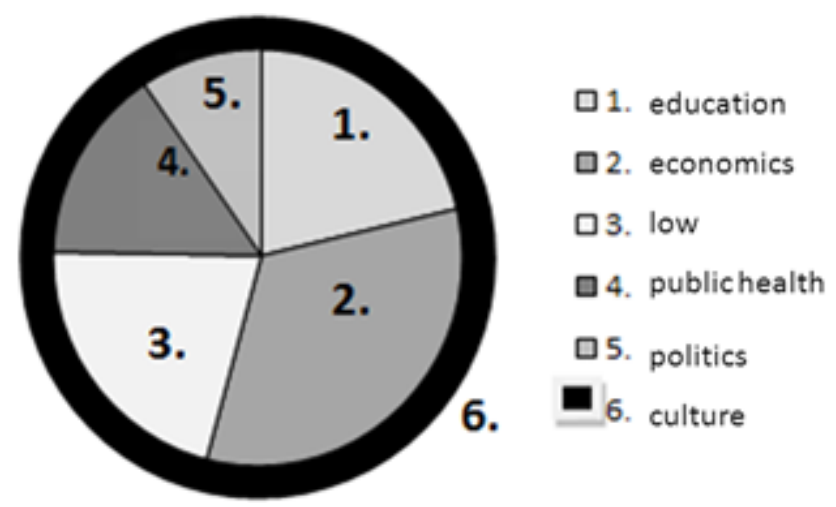

Figure 2. The ideal proportion of sectors on national level

On national level, there is an appropriate proportion among the essential sectors. Culture covers all the sectors, and the two largest ones are economy and education. While politics is the smallest part, but it also depends on culture. Opposite to it, economy determines everything in a global society, while culture can only be a "remainder". In this case, traditions and thinking are irrelevant; the power of money rules everything.

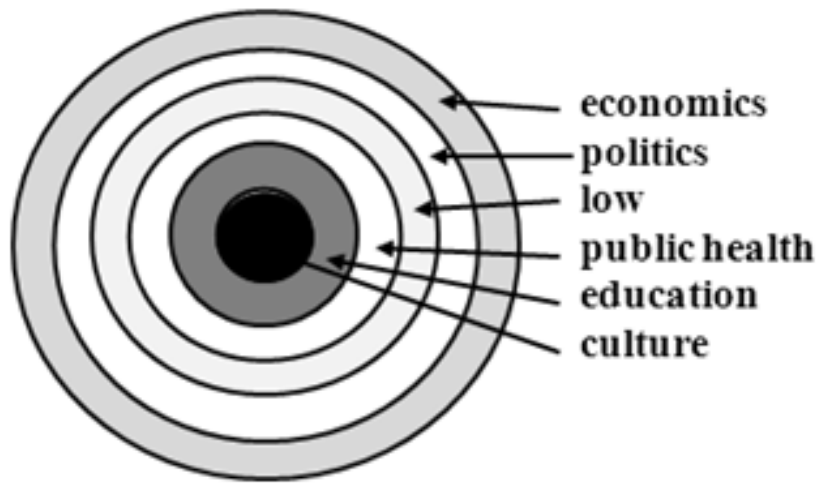

Figure 3. The proportion of sectors in a global world scheme

The most important is to see the relations between economic culture and language. In my opinion, it is the base of important mutations in language and lexical increasing. Culture does not only affect the language but it reflects a way of life. Having words for culture and way of life is necessary in every time.

Regarding both horizontally or vertically, these groups/sectors are indispensable for a healthy community. They influence each other and they can only survive in a voluntary and mutual alliance.

This corporation has to be founded on the same code-basis in order to function properly. This code-basis has to characterize both the everyday language and the terminology as well. In this case, it is the economic terminology that changing every time. First cause of this change is the professions. This is the dominant group of language-modifications, which under international pressure adopts and uses new words and phrases from other languages. Today, "the intensifying role of English language and its impact on other languages mean a new task/duty both for 
experts applying technical terms and for linguists." 1

In the middle of the last century, terminologies used to be different for the various professions, but - especially because of the "internationalization" of the language of media - they were mixing and created a new group of language with many terms from different disciplines: such as law, economics, administration, politics, diplomacy and education, and all the vocabulary that the institutions of the European Community are dealing with. So the first mission for a linguist is that the information should get from one partner to another without distortion, and that the applied terminology should be unambiguous. There is a need on different levels in disciplines to find and create Hungarian equivalents for foreign words, to innovate the language. ${ }^{2}$

We would like to add to this statement of Jerkusné that the official language of EU shall remain for the experts working in Brussells, but we shall try to translate it into our rich mother tongue - with paraphrases if necessary.

Dialects are disappearing from our language today, although the regulated and official literary language became homogeneous only after reformation and neology. This language is a synthetic language formation; it was created from the vocabulary and regularity of dialects.

Our dialects still keep the ancient features of our original language and native culture - including economics too. (for example: csángó, székely - Hungarian-speaking natives of Moldavia and Eastern Transylvania, palóc -, rábaközi dialects in Hungary etc.). It is tragical that the everyday language, which was based on dialects earlier, is full of technical terms today.

When we analyze different disciplines - for example economic terminology - by historical comparative linguistics, we can see that trading, industry and diplomacy mediate words and terms from one language to another faster and faster because of urbanization, state organization and industrial revolution. This fast mediation is due to the permanent appearance and intensive presence of the media. Sometimes people use international words without knowing what they really mean. Several consequences can be expected of this new language style borrowing mostly fashionable English technical words: the creative Hungarian language modifies the received words by analogies, and gives them an individual Hungarian meaning in the everyday language. At last, this meaning will be a synonym of the original word. In other cases, the original phonetic-form remains with uncertain meaning (for example: menedzsment/management; asszisztens/assistant; flow; know-how;). Our everyday language seems to increase in vocabulary, but words having identical meanings (synonyms) are pushed into the background while new words are appearing.

We can observe a strict interaction between the correct usage of language and thinking. If a native language is not identical with itself, that means the proportion of traditional and new parts of vocabulary turns over, then the communication will get confused as well. If our professional thinking adjusts to the "internationalized", strange logic of foreign languages too much, than our language breaks between the different crafts and professions, and the terminology - incomprehensible or easily misunderstandable for an average man - will be the applied language for some privileged groups only. The "interpretational scissors" between economic terminology and everyday language can only be reduced by bringing the economy and common thinking in balance by using the same code system.

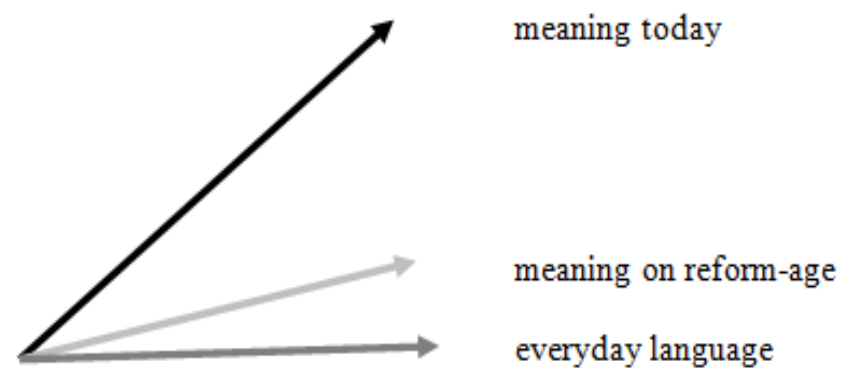

Figure 4. The "interpretational scissors"

Fortunately there are exceptional people, experts, who can bring the economy and the common thinking in balance by using the same code system: specialists who not only analyze the economic processes and give action models, but are able to transmit their ideas and opinions clearly and understandable even for an average man using professional forums or the media. (for example: S, L. Baritz, L. Bogár, I. Boros, K. Lóránt, I.Varga). They can help us to understand that non-professionals today can understand the political and economic processes of the world, and can influence others to act. The key is the knowledge which is able to translate the abstract terminology into everyday language. So the most important criterion - beside special knowledge - is the unity of thinking and language!

\section{Methodology}

I try to analyze some economic terms by using methods of comparative and historic linguistics. My presentation aims to find an answer by examining the modifications of the meaning of some economic terms, showing the constancy or just the modification of our way of thinking by the succession of their synonyms in time.- comparing with Hungarian Vocabularies ${ }^{3}$ with Hungarian and international special linguistic literatures and using literatures of other disciplines (archeology, ethnography, genetic, antropology). I try to study the roots of words by Hungarian Lexical Root Dynamics and Structure Analyzing ${ }^{4}$ which is exploring again. To discover the changes in the language-history, it is inevitable to reveal the well-known history of Hungarian writing.

\footnotetext{
${ }^{1}$ Nyakas [2009]

Jerkus Tibor Istvánné [2009]
}

${ }^{3}$ Marácz - Montvai (2003)
${ }^{4}$ MSzSz [1983], TESz[1995], Ért.KSz[1975], Cz-F[2003] 
I. Origin language (Surviving in Carpatian basin)

(by Cser-Darai)

II. Time of wonder away from Carpatian basin "swarm" - pre-agglutinable (pre-inflective) language

(by Cser-Darai)

III. Language separation by typology

bowmens (,,ijfeszitö") language (agglutinable/inflexible)

(by Bakay, Kiszely; Obrusánszky)

a. Scythian -Hunnish - Turk etc.)

b. Parths - Iranian (by Harmatta)

c. Ugric (by Boda)

IV. Going back to Carpatian basin

(pre-Hungarian language)

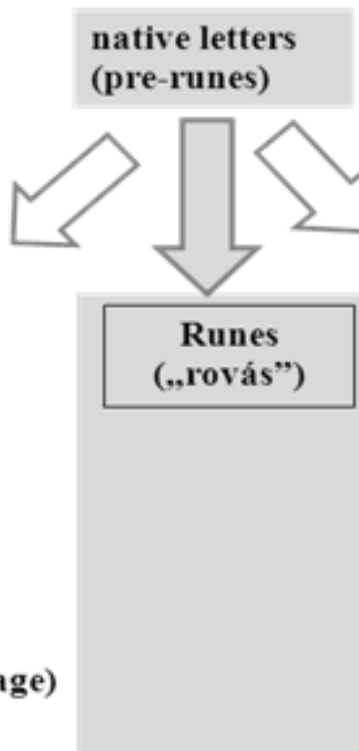

$V$. We start of writening by latin type letters - from the

first literary remains (XI. c. AC) to our time

1. Ancient - Hungarian language

(from migration back to neology)

(Latin and German lingvistics scool)

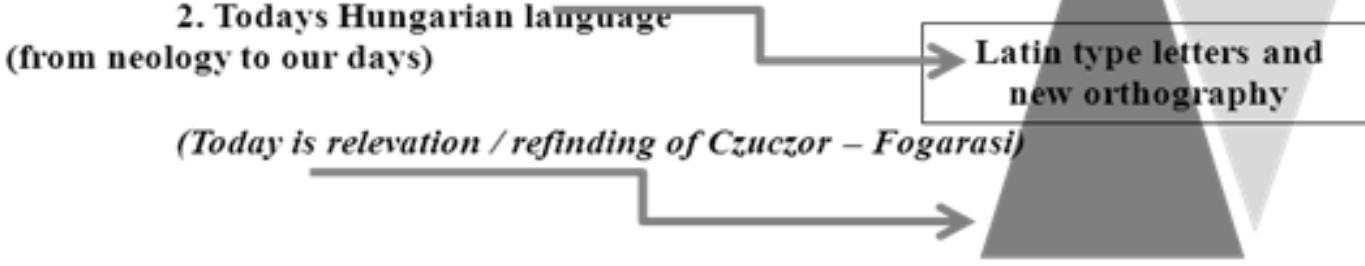

Figure 5. Periods of Hungarian language - by new theories

When we have a look at the periods of Hungarian language, we must not forget the different types of writing: the phonetic symbols of Latin type vocabulary after history, Hungarian runes (mainly the sign of consonants) have been formed for thousands of years until its phonetic structure (not complete) has been developed.

Capable and illustrating thinking in non-fiction literature (let's think of Pusztai, Marcantonio) is the most ancient method/one which was - and still is - characteristic for the ancient agglutinative and complicated Hungarian language. D. Kiss wrote: "We can say about Hungarian language that it is an "ok-os" (cause+-ly = clever/philosophter) language, it proves and makes visible that our words do not mean "vél-et-len-ül" (think+take + chance + by $=$ by chance) that emotional or intellectual something that we all accept later with consensus." ${ }^{5}$

"We can conclude a common ancient language/culture first of all from our language" - said G. Czakó. ${ }^{6}$

\footnotetext{
${ }^{5}$ Kiss Dénes: Az ÖSEGY titka és hatalma, avagy a magyar nyelv tana Püski, Budapest, 1995. (54. p.)

${ }^{6}$ Czakó Gábor: Beavatás a magyar észjárásba - CzSimon Könyvek, Czakó Gábor, 2008. (24. p.)
}

But we could have a deeper look at the history of language: if the theory about the origin of Hungarians from the Carpathian basin is true, ${ }^{7}$ and they migrated from there to the East in several waves, changed from settled agricultural life to steppe culture (partly agricultural, partly animal husbandry, while traveling large territories) - in alliance with or fighting against neighboring people - and traded with nations speaking differently structured languages but still saved their conjugating language together with the pre-historical European culture, than we can suppose that they possessed a very ancient linguistic and cultural treasure. This treasure was completed and colored by the impacts from Asia.

Insisting on evolution, we have to ask the following question: why the youngest language ${ }^{8}$ - which is agglutinative - is the most difficult and most colourful? And we do not have to think of the grammatical structure only but that innumerable group of words which created words from the same root having identical, synonymous or diverse

\footnotetext{
${ }^{7}$ Cser Ferenc - Darai Lajos: Kárpát medence, vagy Szkíthia? - Fríg Kiadó, 2008

${ }^{8}$ Czeizel Endre: A magyarság genetikája - Galenos Kiadó, Budapest, 2003
} 
meanings. Many linguists demonstrated that the more diversified the group of word is, the more ancient notion we are talking about (for example: Pusztai, Marcantonio, Kiss, Marácz, Czuczor-Fogarasi). According to comparative linguistics, the language having the most number of words from the same root for the same notion is the oldest and this language gave the phonetic-form to other languages.

Anthropological and genetical researches confirmed that our nation has the specific coordinating way of thinking, the mainly European character and the ancient cultural similarity or identity and these are also present in other nations who have got a conjugating language too - although they are not in the same "language-family". (That's why we should ignore the classification of "language-family", and we should use typology instead. And similarly we should put aside the phrase "language-development" and instead of it introduce the phrase language change. $)^{9}$

According to scientists, the most conservative and mostly structured type of language is the agglutinative type - among them especially Hungarian. "We do not speak in isolated sentences, but we use sequence of sentences or sentence-like creations.(...) Everybody, whoes mother-tongue is Hungarian, does not repeat the word used earlier while talking about the very same thing, but refers back to it with another 'sparing' language instrument ${ }^{10}$.

Every language carries an ancient formula, and even a small child, who cannot speak his language perfectly, correlates to it too. This is the universal grammar - says Noam Chomsky. However, our language can be traced back to this ancient time with historical-semantical and root analyzing examination.

Analyzing Hungarian thinking linguistic experts (Dénes Kiss, Gábor Czakó, József Molnár V., Marcell Benedek) claim that in the Hungarian way of thinking the human (individual) stands in the middle of the world, and everything is related to this center. At the same time, however, the "me" (the individual person) is not a separate subject, but part of the large totality: it is a member of the family, of the nation etc. So human mentality considering itself as part of the nature is characteristic for the most ancient communities and our language carries this feature as well.

\section{Analyzing the Philosophy of the Hungarian Economic Terminology}

The economic terminology can be found in the Hungarian language from the beginnings. László Bárdi archeologist proved by his excavations that the Huns (ancient tribe of Hungarians) were not only nomads with animal husbandry, but they knew and practiced agriculture and cottage industry. ${ }^{11}$ Accordingly, they did have words and phrases

\footnotetext{
9 Marcantonio (2006)

${ }_{11}^{10}$ Lengyel Zs. im. (136. p)

11 Bárdi: Az ázsiai hunok élete és történelme in: Magyarságtudományi tanulmányok 2008.
}

for these parts of life as well. Kornél Bakay also dealed with it in detail in his works. ${ }^{12}$ The language of the studied ancient cultures is based on the same thinking. Since our language was not modified significantly during the period of Latin type letters (from King St Stephen) and its logic remained as a stone despite of 40 years of socialism, it has not been changed despite of the prevailing tendencies of western liberal financial theories either aiming to modify our consciousness, so we can anticipate that our language mentality is our ancient heritage.

\subsection{Analyzed Terms}

I wish to demonstrate the logic of the Hungarian language by selecting 200 significant economic terms, analyzing their history and the modification or constancy of their meaning.

These words are:

ad (he/she it gives), alku (bargain), ár (price), áru (product), becslés (estimation), befektetés (investment), bank (bank), becs (value), bér(payment), biztosít(provide/ensure), bolt (shop), beszed (cash/collect), birtok (holding possession/ property), bizalom(confidence), cég(company), csal (deceit/fraud), cser él(exchange/barter), csőd(bankruptcy), darab (item, piece), dézsma (tenth), díj(fee, rate, charge), dolog (matter), drága (expensive), eg ész(total), egy (one), él(live) , elintéz(manage), elismervény(voucher), ellát ó(provider) / ás(supply), ellen /érték (equivalent), eloszt (allocate) ás(disposition), előállít(make) ás(production), előír (specify) ás(regulation), előleg(advance/deposit), előny(preference), elszámolás (settlement), elv(principle), eng edmény(concession), épít (built), érdek(interest), érték (value), értelmez $\sim$ és(define, $\sim$ construction), érvény (operation): fedez $\sim$ et (cover, provision), fejleszt $\sim$ és(innovation), fejlödés (development), felel ős $\sim$ ség(responsibility), felesleg(surplus, excess), foglalkoz ás(job)/ tat(employ), foglaló(deposit), fogy aszt ás (consumption)/ ó (consumer), foly amat(procedure), forg alom(circulation), forr ás(source), föld müvelés(agriculture), fuvar $\sim \mathrm{OZ} \sim$ ás (conveyance), gazda-ság(economy), gond os (careful)/ atlan(negligent), gyar apít(enlarge), gyár $\sim \mathrm{t}($ produce $) / \sim$ ó(producer), hagy omány (tradition, custom), halad ás (improvement, progression), hamis ít (forge), halm ozódó (cumulative), haszon(profit), hatalom(power), hatály(force), határidő(deadline), hatás(effect), hiány(deficit), hit el (loan,credit), hozam(yield), hü ség (faith, loyalty), idéz(convene), igény(demand), ill et ék(duty, fee), ing (be loose), ingyen (gratis, for free, without charge), int (make a sign), ipar(industry), ítél et(judgement), jár adék(benefit), jav-ít (improve), jegy (sign), jel (mark), jog (right), jó $\sim$ (good), jöv (edelem)(income), jut-alom (premium), kamat(interest), ker es-kedelem(trade), kincs-tár(treasury),

\footnotetext{
12 Bakay $(1997,2004,2010)$
} 
kockázat (risk,hazard), korlát (limit), kor $\sim$ szerü(up-to-date), köl csön(loan), költ-ség (expense), kötvény(bond), követel(require), lak (home), leh et- öség (possibility, capability), lét $\sim$ esít (create), list $\sim$ a(list)/, magán-(private), mar ad(remain), mennyi-ség(quantity), mér (gauge), mesterség(craft), mezögazdaság(agriculture), minőség(quality), moz gás (motion, movement), munka(work/job), mü (work), norma(standard), növekedés(growth), nyer $\sim$ (win), nyers (raw,rough), nyil ván(evidently), nyom (trail), ok(cause), oszt ás(dividing), óv (save from), örök ös (perpetual/ heir,successor)/ $\sim \operatorname{ség(inheritance),~\quad ~össze~} \sim$ (together), öt $\sim$ let(idea), pálya (vocation), panasz (complaint), paz arlás(waste), per (lawsuit, process), pénz(money), piac(market), pót (back-up), rak (put/set/lay), rang (status), rend $\sim$ (order), rész $\sim$ (part of), rög $\sim$ (soil), rug alm(elastic), saj át(own/private), segít (help/aid), sel ejt (junk,waste product, reject), sik er(succes), sik kaszt (embezzle), sor $\sim($ row/line), $\quad \operatorname{szabad} \sim($ free), szabály $\sim \mathrm{Oz} \quad$ (regulate), szakma(job), szállít (transport), szám(number), szav aatol (guarantee/warrant), százalék(percentage), szer (implement/appliance), szok ás (convention), szolg ál(serve), szöv $\sim(c o o p e r a t i o n), \quad$ szük $\sim \operatorname{ség(need),~}$ táj (region), tak arék (saving), tám ogat(support, back up), tan ács(advice), tap asztalt(experienced), tárgy al (negotiate, confer), tár (open, depot), tar tós(lasting, permanent, static), teh $\sim$ er (burden, freight, load), tel (full), tény $\sim$ (fact), ter $\sim$ (produce, grow), terv(plan, project), tét (stake), tiszt es ség(respectability), tök élet $\sim$ (perfect), tör (break), tőzsde(stock market, exchange), tulajdon os( owner), új (new), ur alom (control, regime), utal (imply, refer), utasítás(order, directive), ügy(matter, issue), ür (space, vacuum), üz (business, deal), vád(blame, accusation), vagy on (fortune, property), val (something), vál (take, assume), ván dorlás(wandering), váltó(bill), valuta(currency), vám(duty), vár ható(expected, due), von ás (mark, line, drawing), vásár lás(purchase), váz ol(draw), véd elem (protection, safeguard, defence), vendég $\sim$ (guest, visitor), vesz/vétel (purchase), vetély társ (rival), vez (manage, direct), vid ék (country, region), világ $\sim$ (world), visz $\sim$ (carry, take), vita $\sim$ (discussion, dispute, conflict), vizsgálat (inquiry, inspection, examination, survey, test), von atkozó (relative), zálog/ levél/ tárgy (collateral, pawn), zuh an (fall, collapse, slump, tumble).

\subsection{Examples}

I chose the most descriptive and characteristic ones from these words:

$\mathrm{AD}$ (give) (_vC), ADÓ (tax): The original meaning is "unsolicited, present". By word lists of economical vocabulary, ${ }^{13}$ the greatest number of terms means:

13 Bajnóczi Beatrix - Haavisto Kirsi: Angol-magyar, magyar-angol gazdasági szótár, Grimm Kiadó, Szeged,2011 vendor/seller. It shows terms of regardless approach of an administration, of a threatening authority.

AL-k (-vC) Alku (bargain): originally it means the honorable agreement, today it means war, victory too.

ÁR- (-vC) (price): If we consider the first root's meaning (damaging, plunder) too: then the price as an economic term does not mean the real value, but it refers to the price determined by somebody (opposit of them: becs-böcs-/value). The meaning of (árad) (rise, flow, grow) presents the permanent mobility of value.

ÁRU (- vC) something which has a price; by one of the definitions of $\mathrm{Cz}-\mathrm{F}$ is the next sentence: "It is an article/product of honest merchants and shopkeepers" - it was one of the characteristics for Hungarian economy at that time.

BECS / BÖCS: (CvC) (value): value, price, measurement, as bailer it is an extinct word.

BÉR (CvC): Be(inside)+éR(value, credit, merit) probably somebody's or something's real inner value, measured by a payment and by remunerating. Opposite to it, its actual meanings are almost all about money.

CSŐD $(\mathrm{CvC})$ : original meaning: assembled crowd, tumult; the language reform, the neology brought the meanings bad news, danger, bankruptcy, collapse. ${ }^{14}$

EG (-vC) +ÉSZ: totality, completeness; (ld: EGY one $>$ EL' $>$ ELV $>$ EL' $>$ ELV $>$ ÖS (ancestor) $>$ ISTEN (God))

FIZ $(\mathrm{CvC})+\mathrm{ET}$ : pay (see: to stitch, to bind, osier, willow / runic-stick/ ect. as a verbal noun);

$\mathrm{FOR}(\mathrm{CvC})+(\mathrm{o})+\mathrm{G}+\mathrm{ALOM}$, : buying and selling; active trading; turning round, rotation, spinning by roots;

FÖL $(\mathrm{CvC})+\mathrm{D}$ : world, earth, land, field, humus; föl-, fel(up) (esetleg: p>f: pöl/pal-ást(cloak)

GAZ (CvC)-DA: owner, possessor, farmer, cultivator; This role is to satisfy the essential needs of life: housekeeping.

JOG(CvC): JÓ/JAV - right hand, good, nice, well, truth, justice;

$\mathrm{HALM}(\mathrm{CvC}-\mathrm{C})+\mathrm{OZ}$ (accumulate, hoard, store and heap, pile): originally: hills made above dead /corpse;

$\mathrm{HAT}(\mathrm{CvC})+\mathrm{AL}+\mathrm{M}+\mathrm{AZ}$ : capable to do $\mathrm{sg}+$ domination + empower to; by originaly means: take, deprive, confiscate, penetrate;

HI (Cv-)+ÁNY: lack of something, emptyness, vacuity, privation, want (vö. HEON - HB) without sg;

HIT $(\mathrm{CvC})+\mathrm{EL}$ : belief, conviction, certainty; credit; loan (honour by confidence); The original economic meaning is belief, 'truth of the given word' too.

ÍG+ÉR+ET : promise, trustworthy, 1138: Egíríh: ÉG(sky, heavens) +ÍR(write) it possible: swear under/for/before God

$\mathrm{KER}(\mathrm{CvC})+($ ESKEDELEM $)$ : The meaning of economic term in our days is trade, commerce The root is ker-/kör, every old meaning includes the circle, circulate, round.

ÖR(-vC)+(ÖK): eternal, endless, something that existed at

\footnotetext{
14 Bajnóczi Beatrix - Haavisto Kirsi: Angol-magyar, magyar-angol gazdasági szótár, Grimm Kiadó, Szeged,2011
} 
all times and will exist forever, complete in itself, full, total; maybe ' $\mathrm{K}$ ' had weared away from start of word; (örv-collar, örvény -whirlpool, eddy, $<$ circle, round, ring

ÖSZ(-vC)+ : (ÖSZVE) together, 1350: ufve; ös- >ösz>összesség (going to the origo /God) as: complete, full, total

PÉN $(\mathrm{CvC})+(\mathrm{e}) \mathrm{Z}$ : money 1211: Peneze (pénze) somebody's money. If we accepted the Slavish origin of the word, it still would show relativity with ancient Hungarian roots: pe-/pö- /pü/pi-> fe-/fö-/fü-/fi- (there are heads, king's portrets on coins). So these meanings are real inner value

SOR (row, line)/ SZOR (multiply) /SER (grow) / SZER (order, right) $(\mathrm{CvC})$ : one after the other, normal, regular, tight, close;

TÖK(CvC)+E: 1293: Egurthuke - foot, stock of alder tree; The meaning in our days is: profitable wealth, property.

TÖZSDE: 1843: tőzsér>tőzs+de word from neologism; money market. Origin: TÖZS $(\mathrm{CvC})+$ ÉR: 1419: Tewser; 1506: Iudas, álnok tỏfeer; O iudas gonoz fefwen; merchant shopkeeper; germ: deceiver, fraud shopkeeper;

TUL $(\mathrm{CvC})+(\mathrm{AJDON})$ : own, personal property; It suggests: the property used to belong to the community. (see: St Crown-doctrine - old Hungarian constitution).

ÚR(-vC)+ALOM: reign, control (URu gentleman, owner +SZÁG lord= ország country, state) 1002/1257; Hurhyda; uros- férfi, vitéz, hős (man, gentleman, valiant, gallant, knight, hero; 1786: urodalomba (property);

VÁS(CvC)+ÁR: purchase and the open air place of buying and selling; 1055: uuafara; purchase, market, see: (Persian) wāzār; It must analyze: vas (iron) had meaned: metal originally; Vás-ár would be means: the place of buying and selling by iron-money.

VESZ(CvC): take 1130: Wevdi. Take something into one's hands - that shows the original meaning.

VIL(CvC)+ÁG: our days: World, Earth, Universe 1195: vilagbele; light, illuminate, shine $>$ World, Earth, Universe (relationship between God and people) > international;

ZÁL(CvC)+OG: collateral, pawn; 1416: zalagba (to pawn); TESZ says: it is originally a Slavic word. But: see: ZAL-/SZAL- stripe, ribbon, band, strap, thong.

\section{Conclusions}

Based on the previous examples, we can state: Hungarian economic terminology is a correct reflection of folk thinking until the reform ages. Analyzed words (originated from the roots: ad-, ár-, bér, ér-, gaz-da-, íg-, ír-, ker-, kin-cs-, ör-, sor-/szer-, tők-, ve-/vé- vil-,), which existed at the beginning of Hungarian writing using Latin letters, still carry the original meaning and logic in their word-group even until today. They indicate every step of the discrepancy from the clear, human-centered economics. According to basic linguistic philosophy, the economy of the so called "archer-nations" (using bows)and the 'scythas' (Huns, Celts, Awars, Hungarians) were based on belief, trust, confidence, on correct and real inner values. This attitude must have differed strongly from the European methods of industrialization and finance, so Hungarian language was not able to reflect the profit-oriented economic thinking until it became a universal economic practice, affecting people. Széchenyi wrote in The Credit (Hitel): "I speak about credit and what is coming from it: about honesty, about the holiness of a given word, the straightness of deeds ..."15

Examining the interpretations, we can see that we took over/back some phrases with negative meaning from some borrowing languages. It can have several reasons. First, the marked activity was strange/different from our own customs, thinking, and habits. Second, distance or antipathy toward the other nation/language.

The listed examples, language modifications support the idea of Sarolta Laura Baritz during a presentation in Sopron ${ }^{16}$ : "if the mentality of someone is changing, the structure based on it changes as well." From the two approaches standing parallel and opposed in the same time by the economist nun, the changes of Hungarian language-philosophy prove our original virtue-ethical thinking. "While in a profit-oriented economy people are for the economy (people are tools), so in the virtue-ethical version economy is for people (people are subjects not objects of economy)." As Baritz demonstrated: the consequence of profit-oriented economics is: people becoming individuals create only a crowd, a mass, while in the virtue ethical economy people create a real community based on common values and mutual interest. ${ }^{17}$

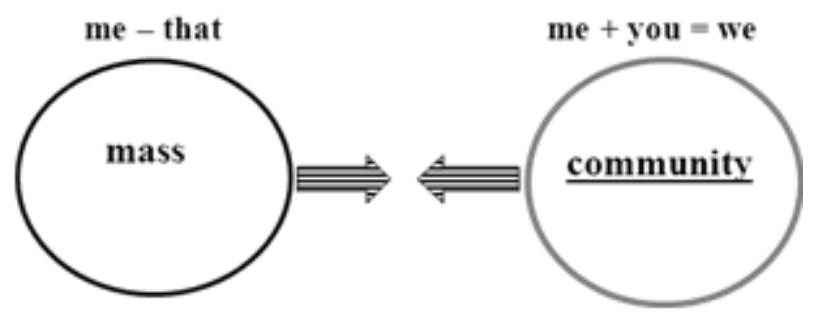

Figure 6. The profit-oriented and virtue-ethical thinking by Baritz ${ }^{18}$

This way of thinking intensifies the willingness for good, the objectivity and the real self-interest - and above this and first of all - it serves the created world. It is a round whole, which means, it is an unit.

Because our Hungarian language and the creativity of our way of thinking follow this economic philosophy, so the order of values for the economists' branch and their vocabulary should be harmonized. One method could be teaching 'language-culture and language philosophy' for a semester at universities, when students would have the opportunity to get acquainted with the meanings of technical terms, or another way could be reading manuscripts of

\footnotetext{
15 Széchenyi (1901.)

16 Baritz Sarolta Laura előadása 2012. március 28. Sopron, NyMEKTK Közgazdász Klub

17 Baritz (2012)

${ }^{18}$ Baritz (2012)
} 
publications on this topic. The "interpretational scissors" between economic terminology and everyday language can only be reduced by bringing the economy and common thinking in balance by using the same code system. One of our tools is beside the cleaning the economic terms from other disciplines, is to bring them on to common denominator. Mainly with an economic philosophy, which is able to achieve that economics becomes the economics of the public/community indeed!

\section{REFERENCES}

[1] A magyar nemzet története Arcanum CD-room

[2] A magyar nyelv könyve (1997) Trezor Kiadó Budapest A. Jászó Anna szerk.

[3] A magyar nyelv történeti-etimológiai szótára I-IV. (1995) Akadémia Kiadó Budapest

[4] Avarok, bolgárok, magyarok (2009) Napkút Budapest

[5] Bakay Kornél (2010): Hogyan lettünk finnugorok?

[6] Bakay Kornél (1997): Kik vagyunk? Honnan jöttünk? Betüvető Kiadás Szombathely

[7] Bakay Kornél (2004): Magyarnak lenni büszke gyönyörüség! Kráter Pomáz

[8] Barabási László (2006): A székely rendtartás Fríg

[9] Baráth Tibor (2008): A magyar népek őstörténete Budapest Püski

[10] Baráth Tibor (1989): Tájékoztató az újabb magyar őstörténeti kutatásokról Veszprém Turul

[11] Bárdi László (2007): Kelet népe vagyunk Helikon Kiadó

[12] Benedek Elek (1898): A magyar nép múltja és jelene Budapest Athaeneum reprint

[13] Boda László (2010): Az ugorok Budapest Szó-fia kiadó

[14] Czeglédi Katalin (2007): Szkíta-hun nyelv östörténete Farkas Lőrinc Imre Könyvkiadása

[15] Czeizel Endre (2003): A magyarság genetikája Budapest Galenos Kiadó

[16] Czuczor Gergely - Fogarasi János (2003): A magyar nyelv szótára Arcanum CD -room,

[17] Cser Ferenc - Darai Lajos (2008): Kárpát medence, vagy Szkíthia? Fríg Kiadó

[18] Cser Ferenc - Darai Lajos (2008): Európa mi vagyunk I -II. Fríg Kiadó

[19] de Groot, J.J.M. (2006): Hunok és kínaiak Budapest Respenna, Bakay Kornél közreadása

[20] Deák István (2008): A szent királyságtól a Habsburg-uralomig Budapest Magyar Ház

[21] Friedrich Klára - Szakács Gábor (2003): Kárpát-medencei birtoklevelünk a Rovásírás Szakács Gábor kiadása

[22] Gerencsér Ferenc szerk: Magyar Történelmi Kronológia I - III. Tárogató Könyvek

[23] Hajdú Péter - Domokos Péter (1980): Uráli nyelvrokonaink Budapest Tankönyvkiadó

[24] Hajdú Péter (1988): Az uráli nyelvészet alapkérdései Budapest Tankönyvkiadó

[25] Honvári János szerk.(2003): Magyarország gazdaságtörténete a honfoglalástól a 20. század közepéig Aula

[26] Huszka József (2000): Tárgyi ethnografiánk ősi vonatkozásai. Debrecen

[27] Jerkus Tibor Istvánné Kovács Erika (2009): Euroterminológia és a magyar gazdasági szaknyelv. MANYE Eger

[28] Juhász Zoltán (2006): A zene ősnyelve. Fríg Kiadó

[29] Kiss Dénes (1995): Az ÖSEGY titka és hatalma, avagy a magyar nyelv tana. Budapest Püski

[30] Kiszely István (2000): A magyarok eredete és ősi kultúrája I II. Budapest Püski

[31] Krantz, Gover S. (2000): Az európai nyelvek földrajzi kialakulása. Budapest Örökségünk Alapítvány - ford: Imre Kálmán

[32] László Gyula (1997): A honfoglaló magyar nép élete. Budapest Püski

[33] László Gyula (1999): Múltunkról utódainknak I-II. Budapest Püski

[34] László Gyula: Östörténetünk - Egy régész gondolatai néppé válásunkról Budapest Tankönyv Kiadó

[35] László Gyula szerk (1983): Régészeti barangolások Magyarországon Budapest Panoráma

[36] Magyar Értelmező Kéziszótár (1975): Budapest Akadémia Kiadó

[37] Malonyai Dezső: A magyar nép müvészete Arcanum CD-room

[38] Marácz László dr. (2007): Magyar újjászületés Fríg

[39] Marácz László (1998): A finnugor elmélet tarthatatlansága nyelvészti szempontból in: Turán XXVIII.

[40] Marácz László (1999): Módszertan-elméleti irányelvek a magyar nyelv kutatásához in: Turán XXIX.

[41] Marácz, L - Montvai, A (2003): Numerical Analysis for the Conceptual and Semantic Structures of the

[42] Lexicon in Contemporary Hungarian In: Marácz, László and Attila Montvai. 2003. Numerical Analysis for the Conceptual and Semantic Structures of the Lexicon in Contemporary Hungarian. In: Communication and Culture: Argumentative, Cognitive and Linguistic Perspectives, eds.

[43] László I. Komlósi, Peter Houtlosser, and Michiel Leezenberg, 143-159. Amsterdam: Sic Sat Publications

[44] Marcantonio, Angela (2006): A történelmi nyelvészet és a magyar nyelv eredete Budapest HunIdea 
[45] Marcantonio, Angela (2006): Az uráli nyelvcsalád Budapest Magyar Ház

[46] Molnár József - Simon Gyöngyi (1980): Magyar nyelvemlékek Budapest Tankönyv Kiadó

[47] Nemeskürty István (2006): Mi, magyarok - Történelmünk ezerszáz éve Budapest Akadémiai Könyvkiadó

[48] Nyakas Judit (2009): Idegen nyelvi hatások a logisztikai szaknyelvben in: MANYE Eger

[49] Obrusánszky Borbála (2008): Hunok a selyemúton Budapest Masszi Kiadó

[50] Ormos Mária szerk. (1988): Világtörténet évszámokban I - III. Budapest Gondolat

[51] Pusztai János (1990): A nyelvek bölcsőjénél Budapest Akadémia Kiadó
[52] Sára Péter (1999): Ösi szavaink nyomában iráni és turáni tájakon Budapest Püski

[53] Sima Qian: A hunok legkorábbi története - A Shi-Ji 110. kötete Magyar Ház Könyvkiadó

[54] ford: Du Yaxiong és Horváth Izabella

[55] Simonyi Zsigmond (1905): A magyar nyelv Budapest Athenaeum

[56] Szekfü Gyula (1988): A magyar állam életrajza Budapest Dick Manó, Maecenas 1917/reprint

[57] Széchenyi István (1901): Hitel - Budapest Lampert Róbert (Wodianer F. és fiai ) cs. és kir. udvari könyvkereskedés

[58] Terdzsüman, Mahmúd (1988): Tárih-i Üngürüsz -Madzsar Tárihi - A magyarok története Cleveland, Ohio, ford: dr. Blaskovics József 